\title{
Simulação computacional do comportamento fractal em colônias de bactérias
}

\author{
Vanessa Fernandes da Silva
}

Instituto Federal de Educação, Ciência e Tecnologia do Rio de Janeiro, Paracambi, RJ Lucas Israel Barbiere da Silva ${ }^{2}$

Instituto Federal de Educação, Ciência e Tecnologia do Rio de Janeiro, Paracambi, RJ Thiago Franco Leal ${ }^{3}$

Instituto Federal de Educação, Ciência e Tecnologia do Rio de Janeiro, Paracambi, RJ

Programa de Pós-graduação em Engenharia Mecânica - PPGEM / UERJ

Cassia Isac Gonçalves da Silva ${ }^{4}$

Instituto Federal de Educação, Ciência e Tecnologia do Rio de Janeiro, Paracambi, RJ

Programa de Pós-graduação em Computação - IC / UFF

\begin{abstract}
Resumo. A Natureza traz soluções que devem ser observadas por óticas convenientes, para a adequada compreensão de seus processos e peculiaridades. Em alguns sistemas biológicos, os mecanismos, interações e distribuição dos componentes se dão por meio de estruturas fractais. Por exemplo, a projeção de vilosidades na fronteira de colônias de bactérias, como Salmonella anatum, otimizando a absorção de nutrientes. Diante disto, este trabalho tem como objetivo estudar modelos do tipo DLA (diffusion limited aggregation) presentes na literatura, visando abordar questões que envolvem o crescimento de colônias de bactérias. A partir disso, simular computacionalmente a dinâmica do organismo em foco, observando sob quais condições o comportamento fractal emerge da fronteira desse sistema biológico.
\end{abstract}

Palavras-chave. Fractais, simulação computacional, diffusion limited aggregation

\section{Introdução}

Diversas são as manifestações de padrões fractais na Natureza. As estruturas que exibem esse comportamento têm em sua fractalidade uma solução evolucionária para perpetuar a vida. Os ramos de uma árvore, por exemplo, conduzem sinuosamente suas folhas por caminhos que possibilitem a obtenção de luz solar em meio à competição de espaço imposta por outros indivíduos. Em comportamento semelhante, mas sem a

\footnotetext{
${ }^{1}$ vanessa.fernandes.silva@ hotmail.com

2 lkz.israel@gmail.com

3 thiago.leal@ifrj.edu.br / thiagofranco@ime.uerj.br

4 cassia.goncalves@ifrj.edu.br / cassiaisac@ic.uff.br
} 
imposição de adversários, os brônquios se ramificam continuamente em bronquíolos, um para cada alvéolo pulmonar, assim como o sistema circulatório que, como um arbusto venoso, tem acesso a todas as células do corpo por vias capilares.

\section{Simulação de colônias de bactérias}

Outro exemplo onde esse padrão emerge é a fronteira de colônias de algumas espécies de bactérias, como Salmonella anatum, S. typhimurium e outras [2,3]. Os organismos aglomeram-se, projetando vilosidades que têm, no geral, fins de nutrição e motilidade.
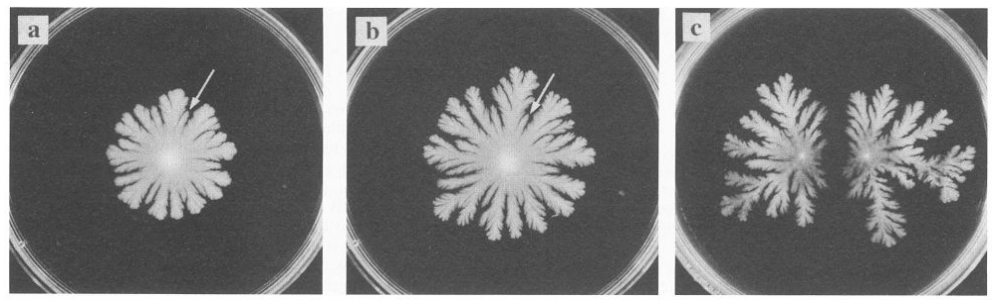

Figura 1: Colônias de Salmonella anatum em (A) e (B), e duas colônias de S. typhimurium, em (C). Figura extraída de [3].

Sobre este contexto, utilizando modelos do tipo DLA (Diffusion Limited Aggregation ) [1,2], o trabalho objetiva realizar simulações computacionais de colônias que apresentam o padrão descrito. Isso possibilitará testar e observar a dinâmica de crescimento da estrutura segundo estímulos externos, como alterações na concentração de nutrientes no meio ou competição entre colônias. Este trabalho configura o projeto de iniciação científica dos dois primeiros autores, sob orientação dos últimos, e está em estágio inicial de desenvolvimento.

\section{Agradecimentos}

Agradecemos ao IFRJ, campus Paracambi / RJ.

\section{Referências}

[1] I. Golding, Y. Kozlovsky, I. Cohen and E. Ben-Jacob, Studies of bacterial branching growth using reaction-diffusion models for colonial development, Physica A: Statistical and Theoretical Physics, vol. 260, 510-554, (1998).

[2] M. Matsushita and H. Fujikawa. Diffusion-limited growth in bacterial colony formation. Physica A: Statistical Mechanics and its Applications, vol. 168, 498-506, (1990).

[3] T. Matsuyama and M. Matsushita, Self-similar colony morphogenesis by gram-negative rods as the experimental model of fractal growth by a cell population, Appll. Environ. Microbiol., vol. 58, 1227-1232, (1992). 